\title{
ZAKRES IMPLEMENTACJI PRZEPISÓW KONKORDATU DOTYCZĄCYCH ZAWIERANIA MAŁŻEŃSTW CYWILNYCH W FORMIE WYZNANIOWEJ DO SYSTEMU PRAWA POLSKIEGO
}

\author{
UWAGI WSTĘPNE
}

W dniu 28 lipca 1993 r. podpisany został Konkordat między Stolicą Apostolską i Rzecząpospolitą Polskąa ${ }^{1}$, który z przyczyn natury politycznej został ratyfikowany przez Prezydenta dopiero 23 lutego 1998 r. $^{2}$ W okresie od podpisania do ratyfikacji konkordatu trwała burzliwa dyskusja nad kształtem jego przepisów. Zarzuty, które stawiano wobec tej umowy dotyczyły zarówno kwestii formalnych, czyli związanych z samą procedurą jej zawarcia, jak i kwestii merytorycznych, tzn. związanych z konkretnymi przepisami zawartymi w tym akcie $^{3}$. Najwięcej kontrowersji wzbudzał artykuł 10 umowy, wprowadzający nową formę zawarcia małżeństwa cywilnego. Zastrzeżenia,

* Dr hab., Wydział Prawa, Prawa Kanonicznego i Administracji, Katolicki Uniwersytet Lubelski Jana Pawła II, Al. Racławickie 14, 20-950 Lublin, e-mail: atunia@kul.pl

${ }^{1}$ Konkordat między Stolicą Apostolską i Rzecząpospolitą Polską, podpisany w Warszawie dnia 28 lipca 1993 r. (Dz.U. z 1998 r. Nr 51, poz. 318).

${ }^{2}$ Ustawa z dnia 8 stycznia 1998 r. o ratyfikacji Konkordatu między Stolicą Apostolską i Rzecząpospolitą Polską (Dz.U. Nr 12, poz. 42).

${ }^{3}$ Szerzej: Wojciech Góralski, Konkordat polski - od podpisania do ratyfikacji (Warszawa: Wydaw. Akademii Teologii Katolickiej, 1998), 24-25. 
które podnoszono w stosunku do tego przepisu, miały zarówno charakter merytoryczny ${ }^{4}$ jak i demagogiczny ${ }^{5}$.

Przedmiotem niniejszego artykułu będzie ustalenie zakresu i sposobu implementacji postanowień konkordatu dotyczących wyznaniowej formy zawarcia małżeństwa cywilnego do krajowego porządku prawnego, to znaczy: czy i w jakim stopniu zostały implementowane postanowienia konkordatu do przepisów ustawowych. Uwagi te poczynione zostaną w kontekście dotrzymania podstawowej dla prawa traktatowego zasady pacta sunt servanda, stosowanej także w odniesieniu do bilateralnych umów zawieranych przez państwa ze Stolicą Apostolską.

\section{TREŚĆ ART. 10 KONKORDATU}

Regulujący wyznaniową formę zawarcia małżeństwa art. 10 ust. 1 Konkordatu stanowi: „od chwili zawarcia małżeństwo kanoniczne wywiera takie skutki, jakie pociąga za sobą zawarcie małżeństwa zgodnie z prawem polskim, jeżeli:

1) między nupturientami nie istnieją przeszkody wynikające z prawa polskiego,

${ }^{4}$ Wśród zarzutów merytorycznych podnoszono m.in. kwestię nieostrości fundamentalnego pojęcia „małżeństwa kanonicznego” użytego w art. 10 Konkordatu, czy zbyt ogólnego określenia warunków zawierania małżeństw. Wojciech Góralski, „Małżeństwo «konkordatowe» (art. 10, ust. 1 umowy Stolicy Apostolskiej i Rzeczypospolitej Polskiej z 1993 r.),” Ateneum Kaptańskie 1 (1996): 69; Jacek Wilk, „Uwagi o zawarciu małżeństwa w formie kanonicznej według konkordatu," Prawo Kanoniczne 1-2 (2001): 233; Paweł Kuglarz, Fryderyk Zoll, Matzeństwo konkordatowe. Analiza prawnoporównawcza zawarcia malżeństwa $w$ prawie kanonicznym i w prawie polskim. Rozważania na tle konkordatu z 28 lipca 1993 r. (Kraków: Staromiejska Oficyna Wydawnicza, 1994), 47-48; Michał Pietrzak, „Zmiany w ustawodawstwie jako konsekwencja ratyfikacji konkordatu," Państwo i Prawo 7-8 (1994): 20.

${ }^{5}$ Wśród tego rodzaju zarzutów podnoszono m.in.: naruszenie ustawowego prawa do milczenia w sprawach przekonań, naruszenie świeckiego charakteru prawa, naruszenie zasady niezależności państwowego porządku prawnego, naruszenie zasady równouprawnienia wszystkich obywateli bez względu na wyznanie, czy utrwalenia przez Konkordat stosowanych praktyk faktycznej bigamii. Małgorzata Winiarczyk-Kossakowska, „List do Tygodnika Solidarność" (cytowane za: Bogusław Trzeciak, Relacje państwo-kościót. O polskim konkordacie (Warszawa 1998), 123); Michał Pietrzak, „Nowy Konkordat Polski,” Państwo i Prawo 1 (1994): 19-20; Jerzy Wisłocki, Konkordat polski 1993. Tak czy nie?, (Poznań: Kantor Wydawniczy SAWW, 1993), 139-140. 
2) złożą oni przy zawieraniu małżeństwa zgodne oświadczenie woli dotyczące wywarcia takich skutków, i

3) zawarcie małżeństwa zostało wpisane w aktach stanu cywilnego na wniosek przekazany urzędowi stanu cywilnego w terminie pięciu dni od zawarcia małżeństwa; termin ten ulega przedłużeniu, jeżeli nie został dotrzymany z powodu siły wyższej, do czasu ustania tej przyczyny".

Owo „wywarcie skutków cywilnych” uzależnione zatem zostało od spełnienia trzech warunków, określanych w doktrynie jako „przesłanki konstytutywne" zawarcia małżeństwa w tej formie ${ }^{6}$.

W art. 10 Konkordatu uregulowano ponadto kwestie dotyczące:

- przygotowania do zawarcia małżeństwa (art. 10 ust. 2),

- kompetencji władz kościelnych i cywilnych w zakresie orzekania o ważności małżeństwa (art. 10 ust. 3 i 4) oraz

- możliwości powiadamiania władz publicznych i kościelnych o orzeczeniach dotyczących ważności małżeństwa w zakresie skutków cywilnych i kanonicznych (art. 10 ust. 5).

Postanowienia art. 10 Konkordatu nie nadawały się jednak do bezpośredniego stosowania i wymagały odpowiedniego uregulowania na szczeblu ustawowym, co zgodne było z brzmieniem art. 10 ust. 6 umowy, który stanowił, iż celem wprowadzenia w życie nowej formy zawarcia małżeństwa dokonane mają zostać konieczne zmiany w prawie polskim. Przepis ten zawierał zatem delegację do podjęcia przez stronę państwową jednostronnych działań zmierzających do przyjęcia - na poziomie krajowym - odpowiednich regulacji wdrażających nowy sposób zawarcia małżeństwa cywilnego.

\section{TRYB I ZAKRES DOKONANEJ IMPLEMENTACJI}

Działania mające na celu wprowadzenie do krajowego porządku prawnego wyznaniowej formy zawarcia małżeństwa cywilnego podję-

\footnotetext{
${ }^{6}$ Artur Mezglewski, „Przepisy wprowadzające w życie instytucję małżeństwa konkordatowego," Roczniki Nauk Prawnych 9 (1999): 260; Wojciech Góralski, Zawarcie małżeństwa konkordatowego w Polsce (Warszawa: Wydaw. Akademii Teologii Katolickiej, 1998), 60-63; Jerzy Strzebińczyk, Prawo rodzinne (Kraków: Zakamycze, 2003), 75.
} 
to już w 1997 r. Racją ich dokonania było nie tylko to, że przepisy art. 10 Konkordatu były dość ogólne i nie nadawały się do bezpośredniego stosowania, ale także fakt, iż uzyskanie przez Kościół Katolicki w drodze Konkordatu możliwości procedowania wyznaniowej formy zawarcia małżeństwa cywilnego, nie mogło być traktowane w kategoriach przywileju przyznanego dla tego Kościoła. Byłoby to sprzeczne zarówno z obowiązującymi w 1993 r. przepisami Konstytucji z 1952 r. uznającej zasadę równości obywateli wobec prawa bez względu na wyznanie (art. 81 ust. 1) ${ }^{7}$, jak też z przepisami Konstytucji z 1997 r., proklamującej zasadę równouprawnienia wszystkich związków wyznaniowych (art. 25 ust. 1) ${ }^{8}$. Było zatem rzeczą oczywistą, że powyższe uprawnienie musi zostać rozszerzone na inne związki wyznaniowe. Rozszerzenie to mogło dokonać się jedynie w trybie ustawowym, ponieważ niekatolickie związki wyznaniowe nie posiadają atrybutu podmiotowości prawnomiędzynarodowej.

Zmiany wprowadzono w dwóch transzach. Najpierw ustawą z dnia 26 czerwca 1997 r. o zmianie ustawy o gwarancjach wolności sumienia i wyznania oraz zmianie niektórych innych ustaw ${ }^{9}$ znowelizowano dziesięć ustaw ${ }^{10}$ regulujących w sposób indywidualny status prawny

${ }^{7}$ Art. 81 Konstytucji Polskiej Rzeczypospolitej Ludowej uchwalonej przez Sejm Ustawodawczy w dniu 22 lipca 1952 r. (Dz.U. Nr 7, poz. 36 z późn. zm.) utrzymany został w mocy na podstawie art. 77 Ustawy konstytucyjnej z dnia 17 października $1992 \mathrm{r}$. o wzajemnych stosunkach między władzą ustawodawczą i wykonawczą Rzeczypospolitej Polskiej oraz o samorządzie terytorialnym (Dz.U. Nr 84, poz. 426).

${ }^{8}$ Konstytucja Rzeczypospolitej Polskiej z dnia 2 kwietnia 1997 r. (Dz.U. Nr 78, poz. 483 z późn. zm.).

${ }^{9}$ Dz.U. Nr 59, poz. 375.

${ }^{10}$ Spośród piętnastu związków wyznaniowych funkcjonujących na podstawie ustaw indywidualnych, przedstawiciele tylko dziesięciu z nich wystąpili formalnie o dokonanie odpowiednich zmian w ich przepisach. Zmiany takie wprowadzono w: ustawie z dnia 4 lipca 1991 r. o stosunku Państwa do Polskiego Autokefalicznego Kościoła Prawosławnego (tekst jedn. Dz.U. z 2014 r., poz. 1726), ustawie z dnia 13 maja 1994 r. o stosunku Państwa do Kościoła Ewangelicko-Augsburskiego w Rzeczypospolitej Polskiej (tekst jedn. Dz.U. z 2015 r., poz. 43), ustawie z dnia 13 maja 1994 r. o stosunku Państwa do Kościoła Ewangelicko-Reformowanego w Rzeczypospolitej Polskiej (tekst jedn. Dz.U. z 2015 r., poz. 483), ustawie z dnia 30 czerwca 1995 r. o stosunku Państwa do Kościoła Ewangelicko-Metodystycznego w Rzeczypospolitej Polskiej (tekst jedn. Dz.U. z 2014 r., poz. 1712), ustawie z dnia 30 czerwca 1995 r. o stosunku Państwa do Kościoła Chrześcijan Baptystów w Rzeczypospolitej Polskiej (tekst jedn. Dz.U. z 2015 r., poz. 169), ustawie z dnia 30 czerw- 
poszczególnych związków wyznaniowych $\mathrm{w}$ państwie ${ }^{11}$. W ustawach tych dodano podobnie brzmiący przepis, w którym przyjęto, iż „małżeństwo zawarte $\mathrm{w}$ formie przewidzianej prawem wewnętrznym danego związku wyznaniowego wywołuje skutki cywilne, jeżeli odpowiada wymaganiom określonym w kodeksie rodzinnym i opiekuńczym" (ust. 1), oraz że „osobę duchowną, przed którą składa się oświadczenie o zawarciu małżeństwa określa prawo wewnętrzne" (ust. 2) ${ }^{12}$.

W następnej zaś kolejności - ustawą z dnia 24 lipca 1998 r. - znowelizowano kodeks rodzinny i opiekuńczy, prawo o aktach stanu cywilnego, ustawę o stosunku państwa do Kościoła Katolickiego w Rzeczypospolitej Polskiej ${ }^{13}$. Na mocy tej ustawy oraz wydanych na jej podstawie aktów wykonawczych ${ }^{14}$, dokonano koniecznego uszczegółowienia

ca 1995 r. o stosunku Państwa do Kościoła Adwentystów Dnia Siódmego w Rzeczypospolitej Polskiej (tekst jedn. Dz.U. z 2014 r., poz. 1889), ustawie z dnia 30 czerwca 1995 r. o stosunku Państwa do Kościoła Polskokatolickiego w Rzeczypospolitej Polskiej (tekst jedn. Dz.U. z 2014 r., poz. 1599), ustawie z dnia 20 lutego 1997 r. o stosunku Państwa do gmin wyznaniowych żydowskich w Rzeczypospolitej Polskiej (tekst jedn. Dz.U. z 2014 r., poz. 1798), ustawie z dnia 20 lutego 1997 r. o stosunku Państwa do Kościoła Starokatolickiego Mariawitów w Rzeczypospolitej Polskiej (tekst jedn. Dz.U. z 2015 r., poz. 14), ustawie z dnia 20 lutego 1997 r. o stosunku Państwa do Kościoła Zielonoświątkowego w Rzeczypospolitej Polskiej (tekst jedn. Dz.U. z 2015 r., poz. 13).

${ }^{11} \mathrm{Na}$ mocy tej nowelizacji niekatolickie związki wyznaniowe już z chwilą wejścia w życie ich ustawy indywidualnej otrzymały de facto możliwość stosowania wyznaniowej formy zawarcia małżeństwa cywilnego, jednak w praktyce, aż do dnia 15 listopada $1998 \mathrm{r}$. nie mogły z niego korzystać, ponieważ do tego czasu nie istniały przepisy wykonawcze, które regulowałyby tryb postępowania przy zawieraniu małżeństwa w tej formie. Szerzej: Strzebińczyk, Prawo rodzinne, 56-57; Artur Mezglewski, Anna Tunia, Wyznaniowa forma zawarcia matzeństwa cywilnego (Warszawa: C.H.Beck, 2007), 19-20.

${ }^{12} \mathrm{~W}$ przypadku Kościoła Katolickiego powyższe przyjęto w drodze nowelizacji ustawy z dnia 17 maja 1989 r. o stosunku Państwa do Kościoła Katolickiego w RP. Do ustawy tej wprowadzono art. 15a, który otrzymał brzmienie: „Małżeństwo zawarte w formie przewidzianej przez prawo kanoniczne wywiera takie skutki, jak małżeństwo zawarte przed kierownikiem urzędu stanu cywilnego, jeżeli spełnione zostały wymagania określone w Kodeksie rodzinnym i opiekuńczym” (ust. 1). „Osobę duchowną, przed którą składa się oświadczenia o zawarciu małżeństwa, określa prawo kanoniczne” (ust. 2).

${ }^{13}$ Ustawa z dnia 24 lipca 1998 r. o zmianie ustaw - Kodeks rodzinny i opiekuńczy, Kodeks postępowania cywilnego, Prawo o aktach stanu cywilnego, ustawy o stosunku Państwa do Kościoła Katolickiego w RP oraz niektórych innych ustaw (Dz.U. Nr 117, poz. 757).

${ }^{14}$ Były to (nieobowiązujące dzisiaj): rozporządzenie Ministra Spraw Wewnętrznych i Administracji z dnia 26 października 1998 r. w sprawie szczegółowych zasad sporządzania 
ogólnych sformułowań konkordatu, umożliwiając tym samym wejście w życie nowej formy zawarcia małżeństwa cywilnego ${ }^{15}$.

W wyniku tej nowelizacji do art. 1 k.r.o. wprowadzono $\S 2$ w następującym brzmieniu: „Małżeństwo zostaje również zawarte, gdy mężczyzna i kobieta zawierający związek małżeński podlegający prawu wewnętrznemu kościoła albo innego związku wyznaniowego w obecności duchownego oświadczą wolę jednoczesnego zawarcia małżeństwa podlegającego prawu polskiemu i kierownik urzędu stanu cywilnego następnie sporządzi akt małżeństwa. Gdy zostaną spełnione powyższe przesłanki małżeństwo uważa się za zawarte $\mathrm{w}$ chwili złożenia oświadczenia woli w obecności duchownego"16.

Ponadto wykonując postanowienie art. 10 ust. 6 Konkordatu uregulowano cały szereg kwestii szczegółowych, tj.:

- tryb złożenia oświadczeń woli jednoczesnego zawarcia małżeństwa podlegającego prawu polskiemu przy zawieraniu małżeństwa wyznaniowego (art. $1 \S 2$ k.r.o., art. $8 \S 1-2$ k.r.o. ${ }^{17}$ ),

- procedurę poprzedzającą zawarcie małżeństwa cywilnego w trybie wyznaniowym (art. 3 i $4^{1}$ k.r.o., art. $54-57$ i 62 a p.a.s.c. ${ }^{18}$ ),

aktów stanu cywilnego, sposobu prowadzenia ksiąg stanu cywilnego, ich odpisów, zaświadczeń, przechowywania i zabezpieczania oraz wzorów aktów stanu cywilnego, ich odpisów, zaświadczeń i protokołów (Dz. U. Nr 136, poz. 884 z późn. zm.); obwieszczenie Ministra Spraw Wewnętrznych i Administracji z dnia 4 listopada 1998 r. w sprawie wykazu stanowisk, których zajmowanie upoważnia do sporządzenia zaświadczenia stanowiącego podstawę sporządzenia aktu małżeństwa zawartego w sposób określony w art. 1 § 2 i 3 Kodeksu rodzinnego i opiekuńczego (M. P. Nr 40, poz. 554).

${ }^{15}$ Artur Mezglewski, ,Artykuł 10 konkordatu z 1993 roku w fazach: ratyfikacji, implementacji do prawa polskiego i stosowania w praktyce," Krakowskie Studia Międzynarodowe 3 (2006): 63.

${ }^{16}$ Natomiast w $\S 3$ art. 1 k.r.o postanowiono, że „Przepis paragrafu poprzedzającego stosuje się, jeżeli ratyfikowana umowa międzynarodowa lub ustawa regulująca stosunki między państwem i kościołem albo innym związkiem wyznaniowym przewiduje możliwość wywołania przez związek małżeński podlegający prawu wewnętrznemu tego kościoła albo innego związku wyznaniowego takich skutków, jakie pociąga za sobą zawarcie małżeństwa przed kierownikiem urzędu stanu cywilnego".

${ }^{17}$ Ustawa z dnia 25 lutego 1964 r. - Kodeks rodzinny i opiekuńczy (tekst jedn. Dz. U. z 2012 r., poz. 788 z późn. zm.).

${ }^{18}$ Ustawa z dnia 29 września 1986 r. - Prawo o aktach stanu cywilnego (tekst jedn. Dz. U. z 2011 r. Nr 212, poz. 1264 z późn. zm.). 
- osobę uprawnioną do przyjmowania oświadczeń o zawarciu małżeństwa (ustawy indywidualne),

- podmiot zobowiązany do sporządzenia i przekazania do urzędu stanu cywilnego zaświadczenia o zawartym małżeństwie (art. 27 ust. 2 p.a.s.c.), sposób i termin jego przekazania (art. $8 \S 3$ k.r.o.),

- procedurę rejestracji w urzędzie stanu cywilnego małżeństwa cywilnego zawartego przed duchownym (art. 61a p.a.s.c.),

- tryb zawarcia małżeństwa cywilnego w formie wyznaniowej w niebezpieczeństwie śmierci (art. 9 § 2 k.r.o.)

Należy jednak zauważyć, iż obecnie - w związku z wejściem w życie z dniem 1 marca 2015 r. nowej ustawy z dnia 28 listopada 2014 r. - Prawo o aktach stanu cywilnego ${ }^{19}$ uchylającej ustawę z dnia 29 września 1986 r. - Prawo o aktach stanu cywilnego ${ }^{20}$ - niektóre wymogi szczegółowe związane $\mathrm{z}$ zawarciem małżeństwa $\mathrm{w}$ formie wyznaniowej zostały zmienione ${ }^{21}$.

\section{OCENA DOKONANEJ IMPLEMENTACJI}

Oceniając zakres dokonanych nowelizacji odpowiedzieć należy na pytanie, czy wprowadzone do prawa krajowego zmiany w zakresie wyznaniowej formy zawarcia małżeństwa cywilnego zgodne były z postanowieniem art. 10 Konkordatu? Podnoszony jest bowiem zarzut, że proces implementacji postanowień tego przepisu do prawa polskiego dokonał się z naruszeniem postanowień zawartej umowy ${ }^{22}$. Naruszenia te miały polegać na tym, że:

${ }^{19}$ Dz.U. z 2014 r., poz. 1741 z późn. zm.

${ }^{20}$ Tekst jedn. Dz.U. z 2011 r. Nr 212, poz. 1264 z późn. zm.

${ }^{21}$ Dotyczy to m.in. obowiązku duchownego pouczenia stron o przepisach prawa polskiego dotyczących małżeństwa i jego skutków (art. 62a p.a.s.c.), który został uchylony, czy też trybu określenia duchownego kompetentnego do procedowania wyznaniowej formy zawarcia małżeństwa (art. 27 ust. 2 p.a.s.c.), który został zmieniony. Szerzej: Anna Tunia, Recepcja prawa wewnętrznego zwiąków wyznaniowych w prawie polskim (Lublin: Wydawnictwo KUL, 2015), 195-202.

22 Mezglewski, „Art. 10 konkordatu z 1993 r.”, 64. 
1) zawarcie małżeństwa kanonicznego miało stanowić bezpośrednią przesłankę zaistnienia małżeństwa w prawie polskim ${ }^{23}$, oraz że

2) zawarte w k.r.o. przepisy nie ujmują wszystkich przesłanek konstytutywnych zawarcia małżeństwa przewidzianych $\mathrm{w}$ art. 10 ust. 1 Konkordatu. Chodzi tu o:

a) nieuwzględnienie jako przesłanki konstytutywnej braku przeszkód z prawa polskiego do zawarcia małżeństwa,

b) nieczytelne uregulowanie przesłanki dotyczącej złożenia oświadczeń woli jednoczesnego zawarcia małżeństwa podlegającego prawu polskiemu i prawu wewnętrznemu kościoła albo innego związku wyznaniowego (oświadczeń o uzyskaniu skutków cywilnych) oraz

c) charakter wpisu małżeństwa do akt stanu cywilnego.

Pierwszy z formułowanych zarzutów dotyczący tego, iżjednostronne regulacje dokonane przez ustawodawcę polskiego nie uwzględniają, a nawet naruszają postanowienia Konkordatu w zakresie zawierania małżeństw cywilnych w formie wyznaniowej, argumentowany jest gramatyczną wykładnią art. 10 ust. 1 umowy, z której wynika, iż to właśnie małżeństwo kanoniczne jest podstawą uzyskania skutków cywilnych $^{24}$. Zgodnie bowiem z literalnym brzmieniem art. 10 ust. 1

${ }^{23}$ Piotr Majer, „Uwagi odnośnie do małżeństwa konkordatowego - art. 10 konkordatu z 1993 r. a ustawodawstwo polskie," Ius Matrimoniale 6 (2001): 150.

${ }^{24}$ Autor tego poglądu tłumaczy, że ,nupturienci zawierający małżeństwo konkordatowe nie zawierają małżeństwa cywilnego, ani też nie zawierają jednocześnie małżeństwa kanonicznego i cywilnego, ale zawierają tylko i wyłącznie małżeństwo kanoniczne, które zostaje przez państwo uznane za ważne w państwowym porządku prawnym”. (Majer, „Uwagi,” 150). Teoria bezpośredniej skuteczności małżeństwa kanonicznego na gruncie prawa polskiego wynika - zdaniem wspomnianego autora - z rozróżnienia między ,fundamentem skutków cywilnych, którym jest małżeństwo kanoniczne oraz przesłankami, czyli warunkami nieodzownymi dla zaistnienia tychże skutków”, co tłumaczyć ma, iż „nupturienci zawierający małżeństwo konkordatowe nie zawierają małżeństwa cywilnego, ani też nie zawierają jednocześnie małżeństwa kanonicznego i cywilnego, ale zawierają tylko i wyłącznie małżeństwo kanoniczne, które zostaje przez państwo uznane za ważne w państwowym porządku prawnym”. (Podobne stanowisko wyraża w: Piotr Majer, „Zobowiązanie małżonków do uzyskania skutków cywilnych małżeństwa kanonicznego," w: Skutki cywilnoprawne matzeństwa kanonicznego ze szczególnym uwzględnieniem prawa w Polsce, Stowacji i Republice Czeskiej, red. Piotr Ryguła (Kraków: Wydawnictwo „scriptum”, 2014), 59; 
Konkordatu podstawę zawarcia małżeństwa cywilnego w formie wyznaniowej (małżeństwa konkordatowego) stanowić ma ,zawarcie małżeństwa kanonicznego"25. Taki wniosek wysnuć można poddając - treść art. 10 ust 1 Konkordatu - jedynie wykładni językowej. $\mathrm{Z}$ całego jednak już kontekstu art. 10 Konkordatu, takiego wniosku wyprowadzić nie można, skoro o skutkach przewidzianych w prawie kanonicznym decyduje władza kościelna (art. 10 ust. 3 Konkordatu), zaś o skutkach cywilnych - sądy państwowe (art. 10 ust. 4 Konkordatu). Władza państwowa nie jest zatem zainteresowana uzyskaniem przez małżeństwo kanoniczne skutków przewidzianych przez to prawo. Jest ponadto niekompetentna w dokonaniu merytorycznej oceny w zakresie tychże skutków. Analizując zatem powyższy przepis (art. 10 ust. 1) nie można oprzeć się jedynie na jego wykładni gramatycznej. Uwzględnić należy wykładnię systemową, uzupełnioną o obszerne uzasadnienia doktrynalne prezentowane w literaturze przedmiotu ${ }^{26}$.

Odnosząc się do drugiego zarzutu stwierdzić trzeba, że kodeks rodzinny i opiekuńczy - w ramach tzw. nowelizacji okołokonkordatowej - nie przejął mechanicznie wszystkich warunków zawarcia małżeństwa, o których mowa w art. 10 ust. 1 Konkordatu.

Piotr Majer, Zawarcie matzeństwa kanonicznego bez skutków cywilnych (Kraków: Wydawnictwo Naukowe Papieskiej Akademii Teologicznej, 2009), 201; Piotr Majer, „Problemy dotyczące zawarcia małżeństwa ze skutkami cywilnymi. Aspekty kanoniczne i cywilne,” w: Przynależność do Kościoła a uczestnictwo wiernych w życiu publicznym, red. Józef Krukowski, Mirosław Sitarz, Bartłomiej Pieron (Lublin: TN KUL, 2014), 166-167). W doktrynie argumentuje się, iż ,teoria ta (...) czyni zarzut przyjętym na zasadzie fikcji prawnej jakoby w momencie zawierania małżeństwa konkordatowego nupturienci zawierali „dwa małżeństwa”: kanoniczne i cywilne. Mezglewski, „Art. 10 konkordatu z 1993 r.”, 64. Z argumentacją tą należy się zgodzić.

${ }^{25}$ Zgodnie z treścią art. 1 § 2 k.r.o. ma to być ,zawarcie [przez mężczyznę i kobietę] związku małżeńskiego podlegającego prawu wewnętrznemu kościoła albo innego związku wyznaniowego w obecności duchownego".

${ }^{26} \mathrm{~W}$ doktrynie - odnośnie do ustalenia podstawy zawarcia małżeństwa - prezentowane są różne stanowiska. Za podstawę zawarcia małżeństwa cywilnego uznaje się: małżeństwo kanoniczne zawarte ważnie z punktu widzenia prawa wewnętrznego danego kościoła lub innego związku wyznaniowego, małżeństwo kanoniczne zawarte ważnie lub nieważnie, małżeństwo zawarte z zachowaniem formy kanonicznej, bądź zaświadczenie sporządzone przez upoważnionego duchownego. Artur Mezglewski, ,Jedno małżeństwo czy dwa? Rzecz o istocie małżeństwa konkordatowego", Monitor Prawniczy 18 (2003): 821-827, i tam cytowana literatura. 
W odniesieniu do charakteru przesłanki braku przeszkód z prawa polskiego do zawarcia małżeństwa w doktrynie panuje rozbieżność poglądów. Wielu autorów uważa, że brak przeszkód nie stanowi przesłanki konstytutywnej zawarcia małżeństwa w trybie art. $1 \S 2$ k.r.o. ${ }^{27}$, inni natomiast uważają, że ich brak jest warunkiem niezbędnym do zaistnienia małżeństwa ${ }^{28}$. Aby ocenić konstytutywny charakter braku przeszkód małżeńskich należy odpowiedzieć na pytanie, jaki wpływ na ważność małżeństwa miałoby faktyczne istnienie którejś z przeszkód wynikających z kodeksu rodzinnego i opiekuńczego. W tym względzie istnieją dwa poglądy. Według jednego z nich faktyczne istnienie przeszkody nie powoduje nieważności węzła cywilnego. Za przyjęciem takiego stanowiska przemawiają m.in. następujące argumenty:

- system polskiego prawa rodzinnego nie zna małżeńskich przeszkód rozrywających ${ }^{29}$,

- przyjęcie, iż przy zawarciu małżenstwa cywilnego w formie wyznaniowej istnienie przeszkody $\mathrm{z}$ prawa polskiego powodowałoby nieważność małżeństwa, łamałoby zasadę równości obywateli wobec prawa ${ }^{30}$.

${ }^{27}$ Góralski, „Małżeństwo «konkordatowe»,” 63-64; Tadeusz Smyczyński, Prawo rodzinne i opiekuńcze. Analiza i wyktadnia (Warszawa: C.H.Beck, 2001), 50-51; Kuglarz i Zoll, Matzeństwo konkordatowe, 54-55.

${ }^{28}$ Jerzy Ignatowicz, „Nowa forma zawierania małżeństw (art. 10 Konkordatu),” Przeglad Sejmowy 2 (1994): 7; Józef Krukowski, ,Zawarcie małżeństwa kanonicznego ze skutkami cywilnymi (art. 10 Konkordatu między Stolicą Apostolską a Rzecząpospolitą Polską)," Roczniki Nauk Prawnych IX (1999): 231-233; Mezglewski, „Przepisy wprowadzające,” 256-259.

29 „Przeszkoda rozrywająca” - to przeszkoda, której zaistnienie powoduje nieważność małżeństwa od samego początku (ex nunc), czyli innymi słowy zaistnienie takiej przeszkody powoduje, że nie zostaje - z mocy samego prawa - zawiązany węzeł małżeński, mimo złożenia przez strony oświadczeń woli o zawarciu małżeństwa i spełnienia innych warunków koniecznych do zawarcia tego związku. Kan. 1073 Kodeksu Prawa Kanonicznego z 1983 r. (Codex Iuris Canonici auctoritate Ioannis Pauli PP. promulgatus. Kodeks Prawa Kanonicznego - przekład polski: E Sztafrowski - zatwierdzony przez Konferencję Episkopatu Polski, Poznań 1984). Szerzej: Cyprian Suchocki, Przeszkody matżeńskie w prawie kanonicznym i polskim kodeksie rodzinnym i opiekuńczym. Poradnictwo rodzinne w aspekcie wymogów Konkordatu (Lublin-Sandomierz: Wydawnictwo diecezjalne, 1997), 15-21.

${ }^{30}$ Pogląd taki prezentowany jest m.in. przez Góralskiego, Zawarcie matżeństwa konkordatowego, 36-38. 
Wydaje się jednak, że należy się skłonić ku stanowisku, iż faktyczne istnienie przszkody uzasadniałoby złożenie skargi o unieważnienie takiego małżeństwa. Decydujące znaczenie w przyjęciu takiego stanowiska ma zastosowanie normy kolizyjnej, która w razie kolizji przepisów o charakterze międzynarodowym z ustawą zwykłą, nakazuje uwzględnić pierwszeństwo tych pierwszych ${ }^{31}$.

A zatem kodeks rodzinny i opiekuńczy nie włącza do katalogu przesłanek koniecznych, przesłanki w postaci braku przeszkód z prawa polskiego do zawarcia małżeństwa. Nieuwzględnienie tej przesłanki nie narusza jednak interesu Stolicy Apostolskiej, a jej zamieszczenie w Konkordacie, poczynione zostało raczej w interesie Strony polskiej. Jednakże $\mathrm{z}$ formalnoprawnego punktu istnieje w tym wypadku kolizja ustawy z przepisami Konkordatu, którą należałoby usunąc $c^{32}$.

Przesłanka dotycząca złożenia oświadczeń woli o uzyskaniu skutków cywilnych określana jest w doktrynie jako,,oryginalny element polskiego konkordatu"33. Różnie też jest traktowana przez przedstawicieli doktryny, to znaczy bądź jako odrębna przesłanka, bądź jako przesłanka skorelowana z przesłanką zawarcia małżeństwa podlegającego prawu wewnętrznemu kościoła albo innego związku wyznaniowego. Implementacja tego warunku zawarcia małżeństwa cywilnego $\mathrm{w}$ formie wyznaniowej nie nastąpiła jednak fortunnie. W kodeksie rodzinnym i opiekuńczym mowa jest bowiem nie o „oświadczeniu woli dotyczącym wywarcia przez małżeństwo kanoniczne takich skutków jakie pociąga za sobą zawarcie małżeństwa zgodnie z prawem polskim” (art. 10 ust. 1 Konkordatu), lecz o „oświadczeniu woli jednoczesnego zawarcia małżeństwa podlegającego prawu polskiemu” (art. $1 \S 2$ k.r.o.). Nie należy jednak dopatrywać się tu naruszenia postanowień przepisów Konkordatu ${ }^{34}$.

${ }^{31}$ Zgodnie bowiem z art. 91 ust. 2 Konstytucji RP, ,umowa międzynarodowa ratyfikowana za uprzednią zgodą wyrażoną w ustawie ma pierwszeństwo przed ustawą, jeżeli ustawy tej nie da się pogodzić z umową".

32 Mezglewski, „Art. 10 konkordatu z 1993 r.”, 65.

${ }^{33}$ Józef Krukowski, Konkordaty współczesne. Doktryna. Teksty (1964-1994) (Warszawa: Civitas Christiana, 1995), 179.

${ }^{34}$ Tadeusz Smyczyński, „Nowelizacja prawa małżeńskiego,” Państwo i Prawo 1 (1999): 25. 
W doktrynie istnieje też różnica poglądów co do roli wpisu małżeństwa do akt stanu cywilnego. Większość przedstawicieli opowiada się za konstytutywnym jego charakterem. Wymóg ten wynika wyraźnie z art. 10 ust. 1 pkt 3 Konkordatu, który stanowi, że „małżeństwo kanoniczne wywiera takie skutki, jakie pociąga za sobą zawarcie małżeństwa zgodnie z prawem polskim, jeżeli [jego] zawarcie zostało wpisane w aktach stanu cywilnego". Konstytutywny charakter tego warunku potwierdzony też został w kodeksie rodzinnym i opiekuńczym, gdzie w art. $1 \S 2$ k.r.o. postanowiono, że dopiero, gdy ,kierownik urzędu stanu cywilnego sporządzi akt małżeństwa (...) małżeństwo uważa się za zawarte w chwili złożenia oświadczeń woli w obecności duchownego". Konstytutywny charakter tego wpisu potwierdził także Sąd Najwyższy w orzeczeniu z 3 marca 2004 r. (II CK 346/02) ) $^{35}$.

W doktrynie istnieją jednak stanowiska, według których wpis ten ma charakter deklaratywny ${ }^{36}$. Argumentem przeciw takiemu twierdzeniu winna być jednak okoliczność, iż ustawodawca polski wprowadzając w życie wyznaniową formę zawarcia małżeństwa celowo ustanowił szerszy katalog przesłanek koniecznych do zawarcia małżeństwa w tym trybie, by uniknąć niepewności, które mogą powstać w okresie między złożeniem przez nupturientów oświadczeń woli wobec duchownego a sporządzeniem aktu małżeństwa w urzędzie stanu cywilnego ${ }^{37}$. W tym celu posłużył się więc retroaktywnością skutków prawnych oświadczeń woli o zawarciu małżeństwa składanych przez nupturientów.

Należy też zauważyć pewną nieścisłość w brzmieniu przepisu Konkordatu i kodeksu rodzinnego i opiekuńczego, gdy idzie o charakter czynności polegającej na sporządzeniu aktu małżeństwa. Art. 10 ust. 1 pkt 3 Konkordatu stanowi bowiem, że „małżeństwo kanoniczne wywiera takie skutki, jakie pociąga za sobą zawarcie małżeństwa zgodnie z prawem polskim, jeżeli jego zawarcie zostało wpisane w aktach stanu cywilnego", natomiast w art. $1 \S 2$ k.r.o., jest mowa o ,sporządzeniu

${ }^{35}$ OSP 2005, nr 2 .

${ }^{36} \mathrm{~Np}$. Rafał Domański, „Konstytutywny czy deklaratywny charakter sporządzenia aktu małżeństwa w przypadku małżeństwa konkordatowego," Państwo i Prawo 3 (2006): 97.

${ }^{37}$ Tadeusz Smyczyński, „Konstytutywny charakter sporządzenia aktu małżeństwa konkordatowego," Państwo i Prawo 3 (2006): 102. 
przez kierownika u.s.c. aktu małżeństwa". I w tym wypadku nie należy jednak dopatrywać się naruszenia postanowień Konkordatu. Użyty bowiem przez Układające się Strony termin ,wpis” miał zostać zgodnie z wolą negocjatorów Konkordatu uszczegółowiony przez ustawodawcę polskiego w ustawie nowelizującej kodeks rodzinny i opiekuńczy. Ze względu zaś na to, że rejestracji stanu cywilnego dokonuje się w formie aktów stanu cywilnego (aktów urodzenia, małżeństwa lub zgonu), spełnienie przesłanki w postaci wpisu małżeństwa oznacza rejestrację zawartego związku ${ }^{38}$. Art. 2 ust. 4 nowej ustawy - prawo o aktach stanu cywilnego z 2014 r. wyraźnie stanowi, że akty stanu cywilnego sporządza się z chwilą dokonania wpisu - o urodzeniu, małżeństwie albo zgonie - w rejestrze stanu cywilnego.

\section{WNIOSKI}

Przeprowadzone badania pozwalają stwierdzić, że nie wszystkie postanowienia art. 10 ust. 1 Konkordatu wdrożone zostały do ustawodawstwa krajowego, zgodnie z jego brzmieniem. Przede wszystkim nie została implementowana do kodeksu rodzinnego i opiekuńczego przesłanka dotycząca braku przeszkód $\mathrm{z}$ prawa polskiego do zawarcia małżeństwa, o której mowa $\mathrm{w}$ pkt 1 tego przepisu. Zastrzeżenia pojawiają się także odnośnie do przesłanki dotyczącej złożenia oświadczeń woli o uzyskaniu skutków cywilnych, o której stanowi pkt 2 omawianego przepisu. Przesłanka ta została bowiem inaczej ujęta na płaszczyźnie kodeksu rodzinnego i opiekuńczego niż w umowie Stolicy Apostolskiej. Powyższe nieścisłości nie naruszają jednak ogólnych gwarancji zawartych w konkordacie, których celem miało być umożliwienie nupturientom wstępowania w związki małżeńskie skuteczne na forum prawa polskiego $\mathrm{w}$ toku jednej, religijnej ceremonii zawarcia małżeństwa.

Implementacja art. 10 Konkordatu nie nastąpiła zatem w pełni, ale Układające się Strony nie podnoszą zarzutu, co do sposobu stosowania go w praktyce. Jednym ze sposobów wykonania Konkordatu jako

\footnotetext{
${ }^{38}$ Góralski, Zawarcie matżeństwa, 59.
} 
umowy międzynarodowej jest późniejsze jego stosowanie. Skoro zatem Stolica Apostolska nie zgłasza zastrzeżeń co do trybu jego wykonywania, uznać należy że jest on prawidłowy. W razie jednak zastrzeżeń, co do stosowania konkretnych postanowień Konkordatu, Układające się Strony przyjęły klauzulę przewidującą możliwość wystąpienia na drodze dyplomatycznej o usunięcie różnic dotyczących interpretacji lub stosowania Konkordatu (art. 28) ${ }^{39}$. Ponadto zgodnie z art. 27 Konkordatu sprawy wymagające nowych lub dodatkowych rozwiązań mogą być regulowane na drodze nowych umów między Układającymi się Stronami albo uzgodnień między rządem i Konferencją Episkopatu Polski upoważnioną przez Stolicę Apostolską.

\section{BIBLIOGRAFIA}

Domański, Rafał. „Konstytutywny czy deklaratywny charakter sporządzenia aktu małżeństwa w przypadku małżeństwa konkordatowego." Państwo i Prawo 3 (2006): 97.

Góralski, Wojciech. Konkordat polski - od podpisania do ratyfikacji. Warszawa: Wydaw. Akademii Teologii Katolickiej, 1998.

Góralski, Wojciech. „Małżeństwo «konkordatowe» (art. 10, ust. 1 umowy Stolicy Apostolskiej i Rzeczypospolitej Polskiej z 1993 r.).” Ateneum Kapłańskie 1 (1996): 69.

Góralski, Wojciech. Zawarcie matżeństwa konkordatowego w Polsce. Warszawa: Wydaw. Akademii Teologii Katolickiej, 1998.

Ignatowicz, Jerzy. „Nowa forma zawierania małżeństw (art. 10 Konkordatu).” Przeglad Sejmowy 2 (1994): 7.

Krukowski, Józef. „Zawarcie małżeństwa kanonicznego ze skutkami cywilnymi (art. 10 Konkordatu między Stolicą Apostolską a Rzecząpospolitą Polską)." Roczniki Nauk Prawnych IX (1999): 231-233.

Kuglarz, Pawel, i Fryderyk Zoll. Matżeństwo konkordatowe. Analiza porównawcza zawarcia matżeństwa $w$ prawie kanonicznym $i$ w prawie polskim.

${ }^{39}$ Expressis verbis przepis ten brzmi: „Układające się Strony będą usuwać na drodze dyplomatycznej zachodzące między nimi różnice dotyczące interpretacji lub stosowania niniejszego Konkordatu". 
Rozważania na tle konkordatu z 28 lipca 1993 r. Kraków: Staromiejska Oficyna Wydawnicza, 1994.

Majer, Piotr. „Uwagi odnośnie do małżeństwa konkordatowego - art. 10 konkordatu z 1993 r. a ustawodawstwo polskie." Ius Matrimoniale 6 (2001): 150.

Majer, Piotr. Zawarcie małżenstwa kanonicznego bez skutków cywilnych. Kraków: Wydawnictwo Naukowe Papieskiej Akademii Teologicznej, 2009.

Mezglewski, Artur. „Przepisy wprowadzające w życie instytucję małżeństwa konkordatowego." Roczniki Nauk Prawnych 9 (1999): 260.

Mezglewski, Artur, i Anna Tunia. Wyznaniowa forma zawarcia matzeństwa cywilnego. Warszawa: C.H.Beck, 2007.

Mezglewski, Artur. „Artykuł 10 konkordatu z 1993 roku w fazach: ratyfikacji, implementacji do prawa polskiego i stosowania w praktyce." Krakowskie Studia Międzynarodowe 3 (2006): 63.

Mezglewski, Artur. „Jedno małżeństwo czy dwa? Rzecz o istocie małżeństwa konkordatowego.” Monitor Prawniczy 18 (2003): 821-827.

Pietrzak, Michał. „Zmiany w ustawodawstwie jako konsekwencja ratyfikacji konkordatu." Państwo i Prawo 7-8 (1994): 20.

Pietrzak, Michał. „Nowy Konkordat Polski.” Państwo i Prawo 1 (1994): 19-20. Smyczyński, Tadeusz. „Nowelizacja prawa małżeńskiego.” Państwo i Prawo 1 (1999): 25.

Smyczyński, Tadeusz. „Konstytutywny charakter sporządzenia aktu małżeństwa konkordatowego." Państwo i Prawo 3 (2006): 102.

Strzebińczyk, Jerzy. Prawo rodzinne. Kraków: Zakamycze, 2003.

Tunia, Anna. Recepcja prawa wewnętrznego zwiąków wyznaniowych w prawie polskim. Lublin: Wydawnictwo KUL, 2015.

Wilk, Jacek. „Uwagi o zawarciu małżeństwa w formie kanonicznej według konkordatu." Prawo Kanoniczne 1-2 (2001): 233.

Wisłocki, Jerzy. Konkordat polski 1993. Tak czy nie? Poznań: Kantor Wydawniczy SAWW, 1993. 
THE SCOPE OF THE IMPLEMENTATION OF THE PROVISIONS

OF THE CONCORDAT CONCERNING CIVIL MARRIAGE

IN A RELIGIOUS FORM INTO THE POLISH LEGAL SYSTEM

\section{Summary}

The object of this article is to analyse the manner and the extent of implementation of the provisions of the concordat between the Holy See and the Republic of Poland (1993) on a religious form of civil marriage contract. The author attempts to determine whether and to what extent the provisions of the Concordat concerning civil marriage and the clergy were implemented into the law. It does so in reference to the commitments undertaken by the contracting parties as the implementation of a treaty law pacta sunt servanda.

Ttumaczenie: Anna Sieradzka-Wawryszczuk

Key words: international agreement, concordat, marriage, civil status records, religious freedom, State-Church relations, freedom of conscience and religion, churches and other religious denominations

Słowa kluczowe: umowa międzynarodowa, konkordat, małżeństwo, akt stanu cywilnego, wolność religijna, relacje Państwo - Kościół, wolność sumienia i wyznania, kościoły i inne związki wyznaniowe 